\title{
An Eclectic Model of Recent LDC Macroeconomic Policy Analyses
}

\author{
RICHARD C. PORTER and SUSAN I. RANNEY \\ University of Michigan, Ann Arbor
}

\begin{abstract}
Summary. - After decades of neglect, there has been a growing concern in the 1970 s with the theoretical and econometric analysis of short-run macroeconomic policy in LDCs. This paper attempts an eclectic synthesis of the recent work on this subject, developing a 'standard LDC model' of aggregate demand and aggregate supply that can be readily compared with the textbook models for advanced economies. Comparative static analyses of monetary policy, fiscal policy, devaluation and wages policy are conducted, and it is shown that the standard macropolicy prescriptions often produce non-standard results. Monetary restriction and devaluation are particularly suspect, as they are likely to produce both recession and price rises.
\end{abstract}

\section{INTRODUCTION}

Over the past decade, there has appeared a serious and growing concern for the problems and potentials of short-term macroeconomic policy in less developed countries (LDCs). From the large literature by many authors on this subject, there are a number of unifying threads. But they are not easily woven together, for the theories are often idiosyncratic and complex and the econometric efforts are necessarily driven by the institutions and data availability of particular countries. The purpose of this paper is to draw together these unifying threads into a single, simple 'standard LDC macroeconomic model' - with the traditional concerns of advanced country macro models for equilibrium in the goods and financial markets and for aggregate demand and supply. With this standard LDC model, it is seen that standard advanced country macro policy prescriptions often yield non-standard results.

Before looking closely at the LDC macroeconomic analysis of the 1970s, we should note the absence of such analysis in the preceding decades. Certainly, in the first years after the Second World War, observers of the newly emerging Third World clearly saw the extensive unemployment and underemployment in LDCs and recognized that a critical objective of economic development was to get the 'unlimited supplies of labour' into productive employment. But early efforts to adapt the growing Keynesian macroeconomic thinking to the problem of economic development were stalled by the appearance of a consensus that planners must worry about long-run growth in the LDCs, not short-run stabilization (Rao, 1952).

While the choice of long-run growth as the first priority is quite understandable, it is nevertheless curious that this meant the neglect, so completely and for so long, of short-run macroeconomic policies which were throughout this period at the very heart of advanced country policy-making. Excess capacity was regulariy observed, but it was just as regularly attributed to entrepreneurial, planning, or micro-market failures. And when inadequate aggregate demand was suspected, it was deplored as beyond the reach of stabilization policies because of the underdevelopment of the financial and fiscal systems of LDCs. Furthermore, economists were discouraged from macroeconomic work by the inadequacies of LDC national accounts data. The requisite series were annual, not quarterly, their pro duction and publication were long delayed, and important elements were casually estimated, often by no more than crude extrapolation.

This neglect of macroeconomic analysis ended in the late 1960 s for two reasons. First, fluctuations in LDCs of the levels of output and prices (or rate of inflation) were increasingly being documented as serious development problems. And second, short-term macroeconomic policy was being practised in LDCs, despite the absence of rigorous theoretical and careful econometric analyses. To some extent, this macroeconomic policy was forced on LDCs by the pressures of internal politics or by 
inescapable constraints, such as the dwindling of foreign exchange reserves. But also, the IMF was 'conditioning' its crisis lending to LDCs on the acceptance of a package of macroeconomic policy restraints. Much of the modelling of the 1970 s arose in an effort to measure the costs and benefits of this package and to make explicit the theory that underlies it.

The theorizing and model-building that has emerged is insightful but complex, and it is not easy to capture its essence in a few pages. In our effort to do so, we are forced to pass over a number of interesting aspects. In our development of a 'standard LDC macroeconomic model', we will focus on the aggregate demand and supply equilibrium and the changes in this equilibrium occasioned by various policy moves. This means that all the interesting dynamics are neglected (beyond an implicit stability analysis). Furthermore, this procedure forces us to ignore the subtleties of lag structures and rigidities; variables either adjust completely in the short run, or they do not adjust at all. Finally, we examine short-run macroeconomic policy and its short-run effects. While some effort is made to indicate the direction of the cumulating, or continuing, effects, there is no formal development here of the long-run growth implications of the various policy tools discussed. In particular, we make no attempt to model changes in expectations nor the role that expectations play in determining policy outcomes.

What is omitted may seem too important to leave much of value, especially to those who have claimed that lags, rigidities and disequilibrium analysis are the essence of shortterm LDC macro understanding (Behrman, 1981; or Crockett, 1981). But we are able to show with these comparative statics that GNP, the price level, income distribution, the balance of payments and the money supply may move awkwardly or perversely - relative to the predictions of the standard MDC (i.e. more developed country) macro model - in shortrun response to the application of the traditional tools of stabilization policy. Showing this possibility is the achievement of the recent LDC macroeconomic literature, and it may be all we can expect until larger, better, and quarterly econometric models begin to yield up more exact and more subtle insights.

The macro model developed here is eclectic in the strict sense. No effort is made to review the literature exhaustively or to attribute specific ingredients to specific sources. For those who would like to read more in this area, we suggest Behrman and Hanson (1979), Cline and Weintraub (1981), and Bruno (1979), where most of the assumptions and relations of this paper are treated more elaborately. The bibliography at the end of this paper is intended as a longer reading list for those who would go still further into the recent LDC macroeconomic literature.

The organization of this paper is as follows. Aggregate supply is discussed in Section 2, aggregate demand in Section 3. The comparative static implications of monetary policy, fiscal policy, devaiuation and wage policy are drawn in Section 4. Some concluding comments are offered in Section 5.

\section{AGGREGATE SUPPLY}

The aggregate supply function of any economy depends importantly on both product and labour market structure, production relationships, and entrepreneurial behaviour. In each of these respects, LDCs are perceived as differing critically from advanced countries.

Oligopoly is more prevalent in the product markets of LDCs. For non-tradables, the sinall economic size of these economies prevents the appearance of a sufficient number of firms to ensure competitive behaviour. And for tradables, the government's strategy of import substitution and its reliance on import licensing to implement that strategy have combined to insulate domestic firms from foreign competition.

Labour markets are notoriously imperfect in LDCs. Blame for a wage structure that badly fails to clear labour markets is variously placed on the colonial legacy, the premature appearance, strength and encouragement of unions, large corporations who pay excessive wages for paternalistic or satisficing reasons, multinationals who coopt their workers by mimicking their advanced country wage structure, and governments with their generous civil service pay scales and minimum wage legislation (Turnham and Jaeger, 1970; and Sen, 1975). Whatever the cause(s), the result is clear-a money wage in the modern manufacturing and commercial sectors of most LDCs that is not responsive to economic forces in the short run and that leaves a significant part of the urban labour force unemployed, underemployed or employed at much lower wage rates in the 'informal' sector. Here, we will capture these complex issues by assuming in the standard LDC model that the money wage rate is fixed in the short run (although we will briefly explore the possibility of a government incomes policy' that alters that wage) and that the 
full employment of labour is not the constraining factor on output expansion.

Due to small economic size and the policies applied to implement import-substitution industrialization, production in LDCs is heavily dependent on imported raw materials and intermediate inputs for which no reasonable domestic substitutes are available. Here, we assume this non-substitutability is complete, so that imported inputs must always comprise a fixed fraction $(m)$ of domestic value added $(Y)$. Labour is the other variable input. The majority view in LDC macro models is that labour inputs exhibit diminishing returns according to the usual neoclassical production function. This is, however, by no means an uncontested view. Where idle capacity accompanies surplus labour, there is scope for expanding output without diminishing returns to labour, provided only that foreign exchange can be located to purchase the needed raw material imports.

Two aspects of entrepreneurial behaviour should be mentioned. First, it is often claimed that the assumption of profit maximization is less appropriate in LDCs, and that some sort of variable-cost-markup pricing is apposite. Second, it is often noted that entrepreneurs in LDCs borrow, from the curb market at the margin, in order to finance their variable costs, so that relevant factor prices for profit maximization or markup calculations must include the interest cost.

What are the implications of these characteristics for the standard LDC aggregate supply curve? They suggest that it is relatively flat in $(Y, P)$ space, with all other variables given. This follows from two aspects of the above discussion: (1) nominal wages tend to be rigid in LDCs, accompanied by an excess supply of labour; and (2) idle capacity suggests that there are not significantly diminishing returns to labour in the relevant range of production. Nominal wage rigidity flattens the aggregate supply curve in the usual neo-Keynesian fashion; an increase in the price level reduces real wages below the marginal product of labour, inducing an increase in employment and thus output. If this marginal product of labour curve is, in turn, quite flat, then the increase in both employment and output due to the increase in the price level is likely to be quite large. This result of a price increase is reinforced by the fact that the price of imported intermediate inputs is also fixed in nominal terms in the short run. In the extreme case of a fixed-coefficients production function (with idle capacity), a cost mark-up equation is perhaps most appropriate. Then the aggregate supply curve becomes completely horizontal.

What happens if we increase the level of output, nearing the region of full employment, or in terms of $Y$, maximum potential output? Clearly, the assumption that the money wage ( $w)$ is fixed in the short run becomes ever less tenable; in such a situation, we would expect increases in money and real wage rates. Various formal approaches are possible, but they all lead to the same result - an ever steeper aggregate supply curve [in $(Y, P)$ space] as maximum output is approached. Thus, the generally upward-sloped aggregate supply curve is seen to have two extremes, becoming very steep as full capacity is reached (the standard MDC case), and very flat if underemployment is accompanied by idle capacity (the standard LDC case).

Variables that shift the aggregate supply curve are those that affect the cost of production. These include the prices of the two variable inputs $-w$, the wage rate, and $e$, the domestic-currency price of foreign currency (normalizing the fixed, exogenous world price of imported inputs at one)-and the cost of the borrowing ( $i$ ) needed to cover these variable costs during the production period. Any increase in cost implies an increase in the price level for the initial level of output to be maintained. That is, an increase in $w, e$ or $i$ shifts the aggregate supply curve up and to the left in $(Y, P)$ space.

In sum, the standard LDC aggregate supply curve is written as: ${ }^{2}$

$$
Y^{S}=Y^{S}(\underset{+}{P}, \underline{i}, \underline{w}, \underline{e})
$$

where the signs of the partial derivatives are shown below the variables. Output, the price level, and interest rate are all endogenous variables in the macro model, while $w$ and $e$ are treated as exogenous or policy variables. The main differences between the standard LDC aggregate supply curve and that usually pictured for an MDC are the following.

(1) The LDC curve is flatter. The MDC is normally 'close' to full employment with less nominal wage rigidity, while an LDC is more frequently found to have not only unemployed labour, but an underutilized capital stock.

(2) The interest rate enters into the aggregate supply curve through its impact on the cost of working capital.

(3) Changes in the exchange rate shift the aggregate supply curve, since the domestic price of imported intermediate inputs and raw materials are affected. 
There is a complication that needs to be considered before leaving the subject of aggregate supply. We must ask more precisely: aggregate supply of what? There are really three different kinds of goods in this model. One, essential raw material and intermediate inputs are imported, but these do not enter into aggregate supply since they are not produced in the LDC. Two, the domestic output that is used to meet the LDC's demands for consumption, investment and government expenditures. And three, exports. This third category of goods differs from the second in that their prices are for the most part determined exogenously and in that their supplies are more often constrained by capacity problems in the short run. Technically, a macro model should consider these differences formally, by introducing two categories of LDC production into the model. We avoid this for simplicity. Here, we think of the aggregate supply of all domestic goods $(Y)$, which are fairly elastically supplied; a portion of these goods is exported, but this portion is fairly inelastically supplied.

\section{AGGREGATE DEMAND}

For LDCs, as for developed economies, the analysis of aggregate demand consists of examining the equilibrium in the markets for the flow of current output and for the stock of money. But many of the institutional ingredients and behavioural relations are quite different in LDCs, and it is necessary to develop these equilibria with some care [Sections 3(a) and $3(\mathrm{~b})$ ]. Each of these equilibria involves three dependent variables - domestic output $(Y)$, the price level of that output $(P)$ and an interest rate $(i)$ - among various exogenous and policy variables, functions and parameters. The two equilibria are combined to derive the aggregate demand relationship between output and price in Section 3(c).

\section{(a) Money market equilibrium and financial markets}

A basic source of the difference in the macroeconomic analysis of advanced and less developed economies is the dramatic difference between them in the structure and activities of their markets for financial assets. In one sense this is obvious, for the very term, "less developed country', suggests if not implies that the use of money is not as widespread and that financial intermediation is not as varied, complex and sophisticated. But there is a second, less innate difference. Government policy in many LDCs has acted to perpetuate, and even exacerbate, the underdevelopment and compartmentalization' of the financial mechanism - a process that McKinnon has termed 'financial repression' (McKinnon, 1973).

The financial underdevelopment of the LDCs is well documented (Goldsmith, 1969). The ratio of financial assets to national wealth (or GNP) is low; the self-financing of investment is prevalent; the spectrum of financial institutions in the 'modern' sector is dominated by commercial banks; and these banks typically do little more than accept deposits and make well-secured loans for working capital purposes. Moreover, the financial system is compartmentalized. Beyond this organized, modern sector that consists largely of commercial banks, there is an extensive 'unorganized' system of curb markets and moneylenders with sometimes unrelated, and generally much higher, interest rates.

One might expect that in the process of development this financial dualism would disappear and a larger, more unified financial system would emerge. But in many LDCs, government policy holds down the nominal interest rates that commercial banks pay on their deposits and charge for their loans. This repression retards the growth of the 'banking habit' and induces non-price rationing in the allocation of cheap commercial-bank credit. Economists generally agree that this policy is foolish - e.g. McKinnon (1973) or Ayre (1977) but LDCs continue to favour it for a variety of reasons: low interest rates are thought to encourage the investment needed for growth; the government debt can be forced onto the organized sector at smaller budgetary cost; usurious profits of monopoly, foreign or disfavoured bankers are prevented; industrialization is encouraged by keeping manufacturers' interest costs low; windfall transfers to the rich are prevented when the saving rate is insensitive to the interest rate; and the lower interest rates of the advanced countries are emulated, in the organized sector at least.

Beside the allocative inefficiencies of financial repression, which are legion but can be ignored here, there are two important implications for macroeconomic modelling and policy. First, a significant part of the financial activity of LDCs takes place outside of the control and direct policy reach of the government. Second, whatever monetary policy is to be practised must be effected by other than open-market operations since the government debt, with its artificially 
Table 1. Elements of the LDC economy's balance sheets

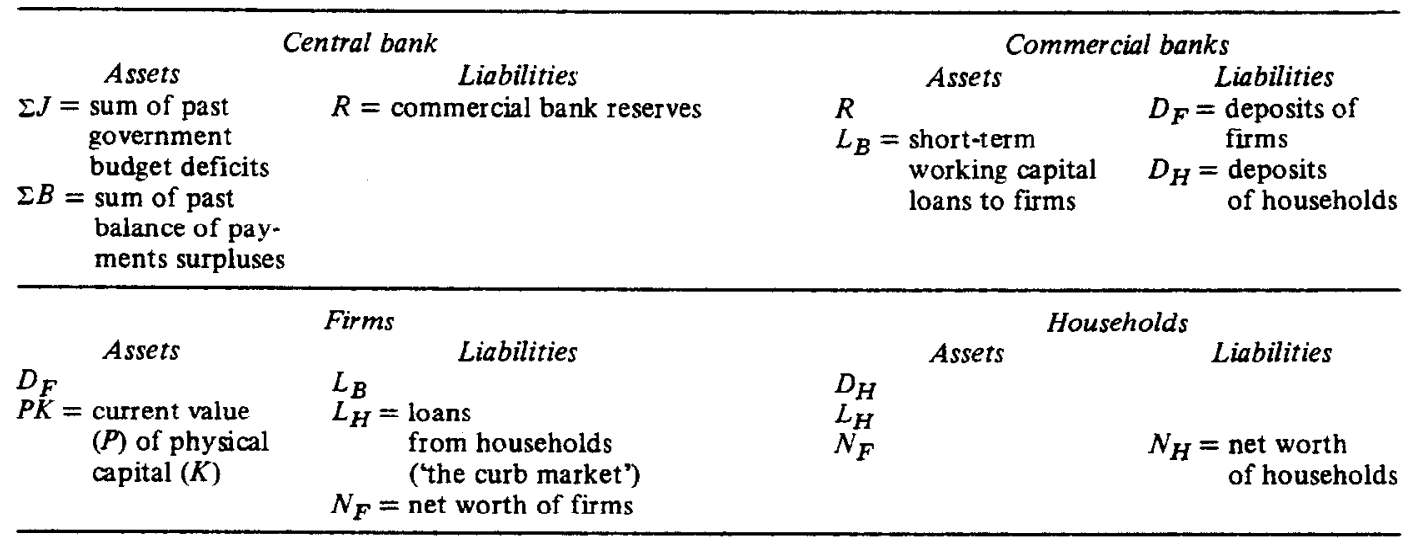

low interest rates, is not bought and sold on a free market. Thus, the central bank cannot affect the monetary base; it is determined by past and current government deficits and trade balances. Changes in the controlled level of the organized sector's interest rates only affect the subsidy on infra-marginal borrowings by favoured commercial bank customers. Monetary policy, which means altering the availability of the organized sector's loans, can be implemented only by changes in reserve requirements [or in liquid-asset requirements if commercial banks are forced to hold government debt (Porter, 1965)].

The principal elements of the LDCs balance sheets can now be seen (Table 1). Four important groups of agents must be distinguished: the central bank, commercial banks (of the organized sector), firms and households. The elements included in these balance sheets are selfexplanatory; what is needed is some discussion of the elements that are omitted. First, currency holdings are ignored. No qualitative insight is gained by including currency, especially since we will also ignore the possibility of interest being paid on deposits. ${ }^{3}$ And second, households (and firms) do not hold foreign exchange. While such holdings are illegal in most LDCs, they are nevertheless important, and the defence for the omission here is simplicity. But it is important to remember that much of the determinateness of the comparative static exercises conducted here would disappear were private foreign exchange movements incorporated. ${ }^{4}$

The determination of financial equilibrium begins with the four balance sheet identities (from Table 1):

$$
\begin{gathered}
\Sigma J+\Sigma B=R \\
R+L_{B}=D_{F}+D_{H} \\
D_{F}+P K=L_{B}+L_{H}+N_{F} \\
D_{H}+L_{H}+N_{F}=N_{H} .
\end{gathered}
$$

The monetary base is determined completely by the sum of past government budget deficits and the sum of past balance of payments surpluses, where in any time period:

$$
\begin{aligned}
& J=\left(w N_{G}+P I_{G}\right)-T \text { and } \\
& B=e(X-M)
\end{aligned}
$$

where $N_{G}$ and $I_{G}$ are government labour and real investment, respectively, $T$ tax revenues, $X$ exports and $M$ imports, noting that the world prices are normalized at unity. Thus, any change that increases the government budget deficit or the balance-of-payments surplus will cause a direct and cumulating increase in the monetary base.

The central bank imposes a reserve requirement ratio $(q)$ on the commercial banks:

$$
R=q\left(D_{F}+D_{H}\right)
$$

Using equations (2), (3) and (8), the supply of bank loans is determined:

$$
L_{B}=(\Sigma J+\Sigma B)(1-q) / q .
$$

Any increase in the monetary base or decrease in the reserve requirement ratio increases $L_{B}$.

The demand for real balances by households is primarily for transactions purposes and is presumably a function of real income $(Y)$ and the interest rates they can earn on alternative assets. For simplicity, we ignore the rates of return of return on capital and firms' equity 
as possible determinants of the households' demand for money, and use only the curb market loan rate $(i) .^{5}$ The demand for real balances by households $\left(D_{H} / P\right)$ is:

$$
D_{H} / P=f_{H}(Y, i) \text {. }
$$

A portfolio theory of the demand for money would also include the households' net worth as an argument in the function.

Firms demand money in order to finance their variable costs during the period of production; these costs consist principally of labour and imported raw materials, and hence:

$$
D_{F} / P=f_{F}[(w N+e m Y) / P, i] .
$$

The firms' demand for real balances is roughly proportional to real expenditures on variable inputs; we thus assume in the standard LDC model that the price elasticity of the firms' demand for (nominal) money is close to one. Although the firms' transactions demand for money may depend on the marginal interest cost $(i)$ as indicated in equation (11), the demand is likely to be quite interest inelastic in the short run, and is so assumed in the standard LDC model.

Eliminating the financial variables in equations (2) $-(11)$ by substitutions, we derive a single equation that defines the financial equilibrium of the economy:

$$
\begin{aligned}
P f_{F}[(w N+e m Y) / P, i] & +P f_{H}(Y, i) \\
& -(\Sigma J+\Sigma B) / q=0 .
\end{aligned}
$$

Equation (12) is the LM equilibrium relationship for the standard LDC economy. It contains three endogenous variables, real output $(Y)$, the price level of domestically produced goods $(P)$, and the curb market interest rate $(i){ }^{6}$ There are two obvious policy variables, the exchange rate $(e)$ and the reserve requirement $(q){ }^{7} \mathrm{At}$ any moment of time, the sum of past budget deficits $(\Sigma J)$ and the sum of past balance-ofpayments surpluses $(\Sigma B)$ are fixed, but policy changes affecting current values of $B$ and $J$ gradually have a cumulative impact on the monetary base.

The $L M$ curve of equation (12) clearly has the usual upward slope in $(Y, i)$ space, with all other ingredients held constant. With a predetermined monetary base, the slope depends on the form of the money demand functions; as long as higher interest rates induce households and perhaps firms to economize on their money balances in order to increase their lending in the curb market and higher income (output) induces both households and firms to increase their transactions balances of money, $i$ and $Y$ must move in the same direction, ceteris paribus. Empirically estimated money demand functions for LDCs invariably reveal these signs. ${ }^{8}$

While it is clear that the $L M$ curve slopes in the same direction in LDCs as in advanced countries, one may less confidently conjecture that the $L M$ curve is steeper in LDCs. The ratio of money to GNP is lower in LDCs, and this may mean that it is largely held for transactions purposes there. If so, the interest elasticity of demand for money will be quite low and the $L M$ curve accordingly quite steep.

The $L M$ curve, drawn in $(Y, i)$ space, will be shifted by changes in any of the other variables in equation (11). The $L M$ curve will be shifted upward and to the left by an increase in any of $P, q, e$ or $w$; and it will be shifted downward and to the right by an increase in either $J$ or $B$, given past government deficits and balance-ofpayments surpluses.

In sum, the $L M$ curve of the standard LDC model is shaped much like that of advanced countries, although it is probably steeper. What is critically different from advanced country $L M$ analysis is: (1) the demand for money depends on both the exchange rate and the wage rate through their impact on firms' variable costs; and (2) many policy changes have not only a direct effect, but also a cumulative effect through changes in the government deficit or balance-of-payments surplus.

\section{(b) Goods market equilibrium}

Equilibrium in the LDC market for domestic production - the IS equilibrium - occurs when the flow of domestic output equals the demand for it. This total demand for domestic output can be divided into the usual four components: household consumption, business investment, government spending and net exports. The recent literature on macroeconomic stabilization models suggests a number of ways in which the stylized facts of each of these components differs for LDCs. These differences are discussed below for each component.

\section{(i) The consumption function}

Real consumption in LDCs depends of course primarily on real disposable household income, just as it does in MDCs. ${ }^{9}$ But for LDCs, there are two other important determinants. One, consumption depends on the functional distribution of income since, it is generally asserted, the marginal propensity to consume out of wage income is higher than the marginal propensity to consume out of profits 
(Houthakker, 1961, and Williamson, 1968). Accordingly, we introduce the labour share of GNP, $S$, into the aggregate consumption function, with a positive partial derivative. The second important difference in the LDC consumption function is that direct income taxes are a less important source of government revenue there. Nevertheless, sales and excise taxes that are closely related to total output in their movements are becoming more widely used in LDCs. We will, for simplicity, include a single 'income tax' rate $\left(t_{y}\right)$ in the consumption function, with a negative effect on consumption. ${ }^{10}$ Aggregate real consumption $(C)$ in the LDC is summarized by the function:

$$
C=C\left(Y, \underline{S}, \underline{t} \underline{y}_{y}\right) \text {. }
$$

\section{(ii) The investment function}

As in MDCs, the level of private fixed investment is assumed to depend positively on the desired capital stock, which in turn is an increasing function of output. The financing of private fixed investment, however, is very different in LDCs. As discussed in Section 3(a), in LDCs business firms use loans from both official and curb markets primarily to finance their short-term working capital. Capital investment is usually financed through direct lending from the government, in which case we will here consider it to be government investment (and treat it under government expenditure), or through retained earnings of business firms. Real retained earnings depend negatively on the real costs of variable inputs. These include real wages, the real price (in domestic currency) of imported inputs, and the average interest paid on loans. This average interest rate is a function of the official bank rate $\left(i_{B}\right)$, the curb market rate $(i)$, and the availability of loans at the official bank rate $\left(L_{B}\right)$. In Section 3(a) [equation (9)] it was shown that $\left(L_{B}\right)$ increases if total reserves $(\Sigma J+\Sigma B)$ increase or the reserve ratio $(q)$ is decreased. Thus the demand for real private investment $(I)$ in the standard LDC model is written as: ${ }^{11}$

$$
I=I\left(\underline{Y}, \underline{i}, \underline{i}_{B}, \underline{J}, \underset{T}{B}, \underline{q}, \underline{w} / P, \underline{e} / P\right) .
$$

\section{(iii) Government spending}

Government spending in LDCs is composed largely of wage payments, where the wage paid to government employees is kept in line with that in the private sector - or vice versa. Thus any decrease in the economy-wide real wage decreases real government spending in the short run. The other important component of real government spending is public sector investment, in which we also include any portion of investment subsidized by the government, either directly or through low interest rate loans. We take this investment as given in the short run, in real rather than nominal terms (in accordance with most evidence - e.g. Aghevli and Khan, 1978).

Real government spending $(G)$ is thus summarized as:

$$
G=G\left(w N_{+} / P, I_{G}\right) .
$$

\section{(iv) Net exports}

Most LDCs are small relative to the rest of the world, and face exogenously determined world prices. Thus, domestic prices of tradables depend on world prices, subsidies and tariffs, and the exchange rate. ${ }^{12}$ As discussed above, the price elasticity of export supply is likely to be small in the short run owing to capacity constraints and the delays always inherent in initiating or dramatically increasing exports. $^{13}$

Imports and domestically produced goods are very poor substitutes. For LDCs that have completed the early stages of importsaving industrialization, the remaining imports consist largely of non-competitive intermediate inputs, which we treat as proportional to domestic output. Thus the income (output) elasticity of import demand is unity, while the direct price elasticity is zero.

Two other aspects of the LDC trade sector should be noted. First, a significant part of the government revenues are generated there in most LDCs - almost all in some. These derive primarily from ad valorem taxes on imports $\left(t_{m}\right)$, but we shall include also a tax on exports $\left(t_{x}\right)$, while remembering that for some LDCs and for some exports subsidies may be offered on exports (i.e. $t_{x}<0$ ). And, second, the trade sector is large in most LDCs, and the serious macroeconomic policy issues seem almost always to arise in the context of a large deficit in the current account.

In sum, the real value of net exports in domestic currency $(N X)$ is expressed as:

$$
\begin{aligned}
N X= & e / P\left[\left(1-t_{x}\right) X\left(e\left(1-t_{x}\right) / P\right)\right. \\
& \left.-\left(1+t_{m}\right) m Y\right]
\end{aligned}
$$

where $X$ is the value of exports, valued in foreign currency.

Formalizing the above stylized facts and incorporating them into the GNP identity yields the following condition for goods market equilibrium (i.e. the $I S$ function): 


$$
\begin{aligned}
Y= & C\left(Y, S, t_{y}\right) \\
& +I\left(Y, i, i_{B}, \Sigma J, \Sigma B, q, w / P, e / P\right) \\
& +G\left(w N_{G} / P, I_{G}\right) \\
& +e / P\left[\left(1-t_{x}\right) X\left(e\left(1-t_{x}\right) / P\right)\right. \\
& \left.-\left(1+t_{m}\right) m Y\right] .
\end{aligned}
$$

This IS curve has the usual downward slope in $(Y, i)$ space. With the stylized facts discussed above, it is likely to be quite steep; the low short-run interest elasticity of investment demand and the high income elasticity of import demand both act to increase the slope. There are, however, two forces acting in the reverse direction, to reduce the $I S$-curve slope: (1) the large overall marginal propensity to consume attributed to low income countries (Behrman and Hanson, 1979; Leff and Sato, 1980); and (2) the possibly high income elasticity of investment demand suggested by some empirical studies (Leff and Sato, 1980).

Policy variables include the three tax rates, government employment, government investment and the exchange rate. The impact of changes in government expenditures and income taxes are qualitatively the same as in a standard MDC macro model. An increase in $t_{x}$ or $t_{m}$ reduces the value of net exports in domestic currency for a given foreign currency balance, thus shifting the $I S$ curve down and to the left. However, this is counteracted to some extent if export supply or import demand are price elastic.

Devaluation of the real exchange rate $(e / P)$ affects the balance of trade and has a negative impact on investment (because the cost of intermediate inputs in domestic currency rises, which reduces current retained earnings). In a general context, without taxes and given constant world prices, the balance of trade valued in domestic currency will worsen with devaluation (for a given level of income) if:

$$
B / e+X \eta_{X S}+M \epsilon_{M D}<0
$$

where $\eta_{X S}$ is the export supply elasticity, $\epsilon_{M D}$ is the (absolute value of the) import demand elasticity, $M$ is imports in foreign currency and $B$ is in the initial trade balance in domestic currency. ${ }^{14}$ The stylized facts suggest that both $\eta_{X S}$ and $\epsilon_{M D}$ are small ${ }^{15}$ and that, at times of macroeconomic crisis in LDCs, $B$ may be a large negative number. Thus we assume that the net effect in the short run of devaluation on the IS curve for the standard LDC is a leftward shift. This effect on the IS locus is known as 'contractionary devaluation' (Krugman and Taylor, 1978).
Notice finally that a change in the real wage rate $(w / P)$ provides an ambivalent impact in the $I S$ curve. A reduction in the money wage or an increase in the price level will shift the $I S$ curve down and to the left through its effect on the wage share and government expenditure, but up and to the right through the effect on retained earnings and hence fixed private investment. In the standard LDC case, we expect the down-and-to-the-left effects of real wage cuts to dominate.

The price level is the third endogenous variable in the goods market equilibrium equation. An increase in the price level implies both a revaluation of the real exchange rate (a decrease in $e / P$ ) and a fall in the real wage (a decrease in $w / P$ ). From the discussion above, the net effect is ambiguous, though probably small. In the standard LDC model, the decrease in the real exchange rate shifts the $I S$ curve to the right, while the decrease in the real wage shifts it to the left. Hereafter, we will assume that the impact of a change in $P$ on the $I S$ curve is zero in the standard LDC model.

\section{(c) The aggregate demand function}

The $L M$ curve, equation (12), and the IS curve, equation (17), can be combined in the usual way so as to remove one of the three endogenous variables, the curb market interest rate $(i)$. This leaves us with an aggregate demand curve that relates price $(P)$, output $(Y)$, and various exogenous and policy variables:

$$
\begin{aligned}
Y^{D}= & Y^{D}\left(\underline{P}, \underline{q}, \underline{i}_{B}, N_{G}, \ddagger_{G}, \underline{t}_{y}, \underline{t}_{x},\right. \\
& \left.\underline{t}_{m}, \underline{e}, \underline{w}, \Sigma_{q}, \Sigma_{q}\right) .
\end{aligned}
$$

While this aggregate demand curve is downwardsloped in $(Y, P)$ space, just like the standard MDC aggregate demand curve, it is likely to be much steeper. There are two reasons for this. First, the IS curve, which shifts to the left in the standard MDC model when the domestic price level rises because of the effect on net exports, does not shift in the standard LDC model. ${ }^{16}$ Second, the IS curve is relatively steep due to a high marginal propensity to import and a low interest rate elasticity of investment demand.

The other signs of the partial derivatives of equation (19) will be discussed in the process of examining policy changes in the next section. But two should be noticed here briefly because of their differences with the standard MDC aggregate demand function. First, the sign for $e$ is the opposite of that usually encountered. This occurs because devaluation increases the 
demand for money and because we are treating 'contractionary devaluation' as the standard LDC case; thus, devaluation shifts both the $L M$ and the $I S$ curves to the left [in $(Y, i)$ space]. Second, the nominal wage rate enters the aggregate demand function and enters it with indeterminate sign. A rise in the nominal wage rate shifts both the $L M$ and the $I S$ curves upward [in $(Y, i)$ space], leaving the net effect on the aggregate demand for output uncertain.

\section{COMPARATIVE STATIC ANALYSIS}

The 'new wave' of short-run stabilization models of LDCs was motivated largely to provide a formal framework in which to analyse the so-called standard IMF policy package, consisting of devaluation and both monetary and fiscal restraint. It is these policies that we focus on here. In addition, we consider an incomes policy that alters the nominal wage rate. In the analysis, we contrast the standard MDC and LDC models; they differ not only because the slopes of the aggregate supply and demand curves are likely to be different, but also, and more importantly, because the supply and demand sides of the economy interact. In particular, in the LDC, changes in labour market conditions (specifically the real wage rate) have a direct impact on aggregate demand, and changes in financial market conditions (specifically the curb market interest rate) have a direct impact on aggregate supply.

The four exogenous variables considered in the analysis are: monetary policy $(q)$, fiscal policy $\left(I_{G}\right)$, exchange-rate policy $(e)$ and incomes policy $(w)$. In each case, we shall note not only the direct impact of the policy change on the economy but also the continuing, or cumulating, effects through changes in the government deficit $(J)$ and the balance-ofpayments surplus $(B)$ and hence through changes in the monetary base. Thus pruned of the exogenous variables that we will not alter, the aggregate supply and aggregate demand curves of the standard LDC model are:

$$
\begin{aligned}
Y^{S} & =Y^{S}(\underset{+}{P}, \underline{i}, \underline{e}, \underline{w}) \text { and } \\
Y^{D} & =Y^{D}\left(\underline{P}, \underline{q}, \neq G, \underline{e}, \underset{?}{w}, \Sigma_{\neq}, \Sigma_{\not{B}}\right) .
\end{aligned}
$$

Before beginning the diagrammatic analysis, two points require attention. First, any change in the $I S-L M$ equilibrium, and hence in the curb market interest rate, can be attributed to one of two alternative causes: (1) an exogenous shift in the $I S$ curve and/or the $L M$ curve due to a change in a policy (or exogenous) variable; or (2) an endogenous shift in the $L M$ curve due to a change in the price level. Thus we can write an equation for the curb market interest rate as a function of the price level and exogenous variables:

$$
i=i\left(\underset{+}{P}, q, \downarrow_{G}, \underset{?}{e}, \underset{+}{w}, \Sigma J, \Sigma \underline{B}\right) .
$$

The signs of the partial derivatives of equation (22) are those appropriate to the standard LDC model. Since the $I S$ curve does not shift with a change in $P$ in the standard LDC model, $i$ unambiguously increases as $P$ does. It is also assumed that the impact of an increase in the money supply (a decrease in $q$ or increase in $\Sigma J$ or $\Sigma B$ ) is dominated by a rightward shift of the $L M$ curve; the increase in investment demand due to the higher retained earnings is relatively small.

Now it is possible to write an aggregate supply function in terms of just two endogenous variables, $Y$ and $P$, by substituting the interest rate function (22) into the aggregate supply function of equation (20):

$$
Y^{S}=Y^{S}[i(\underset{+}{P}, q,\{G, \underset{?}{e}, \underset{+}{w}, \Sigma J, \Sigma \underline{B}), \underline{P}, \underline{e}, \underline{w}] .
$$

The slope of the aggregate supply curve (23) in $(Y, P)$ space is steeper than the aggregate supply curve of equation (20) where $i$ is held fixed. But, for our basic LDC model, we assume that the endogenous increase in $i$ that occurs in response to a price increase is sufficiently small that the aggregate supply curve (23) remains quite flat in regions of unemployment and idle capacity. ${ }^{17}$

Second, changes in exogenous or endogenous variables may affect the monetary base. This is the impact we refer to as the cumulative effect. Changes in exogenous variables are discussed in each section, but here we summarize how changes in $i, P$ and $Y$ might alter the monetary base, remembering that it is composed of the sum of past government deficits and balance-ofpayments surpluses (in nominal terms). Referring to equations (6) and (7), it can be seen that the interest rate $(i)$ is not a direct determinant of the monetary base. An increase in $P$ increases both nominal government spending (to the extent that real expenditures, $I_{G}$, are fixed) and tax revenues (to the extent that there are direct income-related taxes). The net effect is assumed here to be negligible. An increase in $Y$, however, increases imports, reducing the balanceof-payments surplus and increasing import duty revenues, which in turn decreases the government deficit. Thus, the monetary base decreases. A decrease in the monetary base shifts both the aggregate demand and supply 

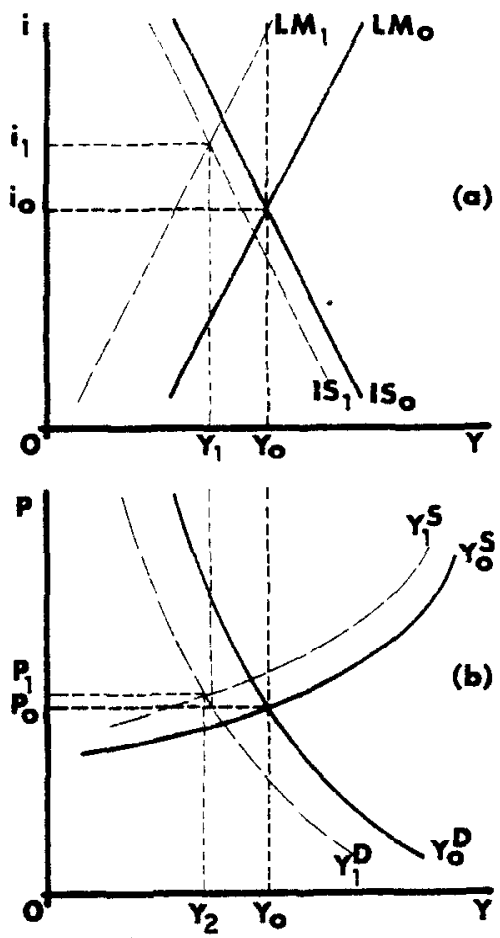

Figure 1. Restrictive monetary policy.
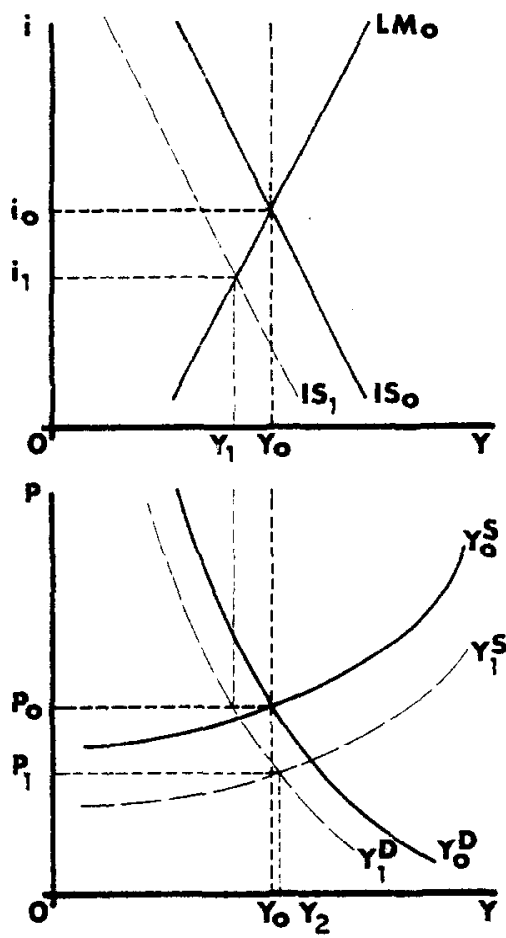

Figure 2, Restrictive fiscal policy. (a)

\section{(b)}

curves to the left, the net impact being primarily a decrease in output.

\section{(a) Monetary contraction}

The impact of monetary contraction in the standard LDC model is shown in Figure 1. The initial position of various functions and endogenous variables is indicated by the subscript, 0 . An increase in the reserve requirement ratio $(q)$, reducing the money supply, has a large impact on the $L M$ curve (for a given price level) because of the low interest rate elasticity of money demand. The decrease in the availability of lowinterest commercial bank loans also reduces retained earnings somewhat, shifting the IS curve down. The new curves are shown in Figure 1(a) with a subscript 1. The rise in $i$, from $i_{0}$ to $i_{1}$, and the fall in $Y$, from $Y_{0}$ to $Y_{1}$, shows us the extent to which the $Y^{D}$ curve shifts to the left, in Figure 1(b), and that the $Y^{S}$ curve shifts upward. The new aggregate supply and demand curves, labelled in Figure 1(b) with subscript 1 , intersect at output, $Y_{2}$ and price $P_{1}{ }^{18}$

The impact of monetary contraction is thus a relatively small horizontal shift in the aggregate demand curve. And, due to the flatness of the aggregate supply curve, any shift that does occur is relatively ineffective in reducing the price level. In the LDC, this restrictive monetary policy also raises the aggregate supply curve through the increase in the interest cost on variable inputs. The net impact of monetary contraction is, for the MDC, that the price level falls and output declines moderately; for the LDC, output also falls, but the price level may increase. In the short run, restrictive monetary policy has few appealing implications for the policy-maker in the LDC economy even the functional distribution of income is likely to worsen as output falls, especially if $P$ rises.

The cumulating effects on the money supply are expansionary. Thus as time goes on, the initial impact of the increased reserve requirement ratio on output will be reversed and the 

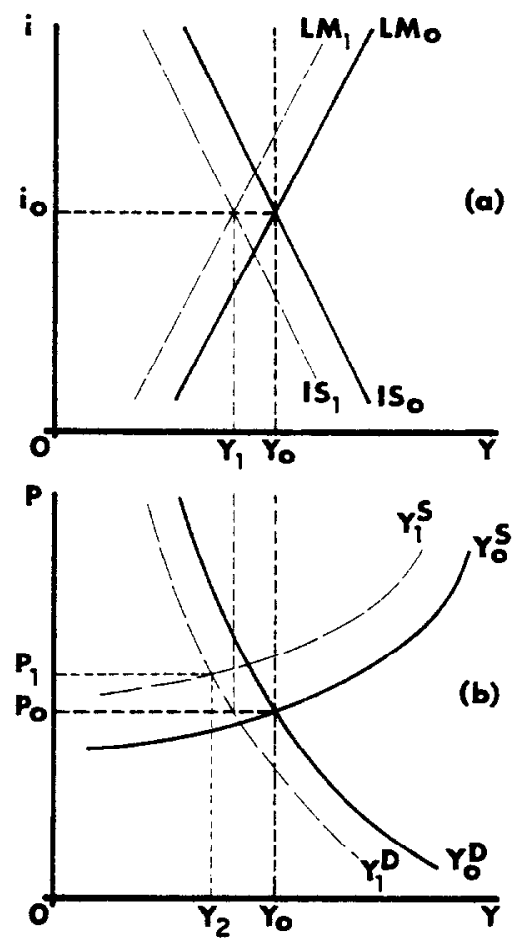

Figure 3. Devaluation.

LDC moves back toward its initial equilibrium level of income.

\section{(b) Restrictive fiscal policy}

While restrictive monetary policy is likely to increase both unemployment and inflation in the LDC in the short run, restrictive fiscal policy is likely to be more successful in reducing the price level without the costs of a major recession. A decrease in government spending shifts down the $I S$ curve, from $I S_{0}$ to $I S_{1}$. This results in a small leftward shift in the aggregate demand curve, from $Y_{0}^{D}$ to $Y_{1}^{D}$ at $P_{0}$, but also a shift down in aggregate supply because $i$ has fallen from $i_{0}$ to $i_{1}$. The net result is a decrease in the price level and possibly even an increase in output. This possibility is illustrated in Figure 2(b) as a rise in $Y$ from $Y_{0}$ to $Y_{2}{ }^{19}$ In the standard MDC model of course, restrictive fiscal policy reduces both $Y$ and $P$.

If the change in output is small for the LDC, then import demand is little affected.
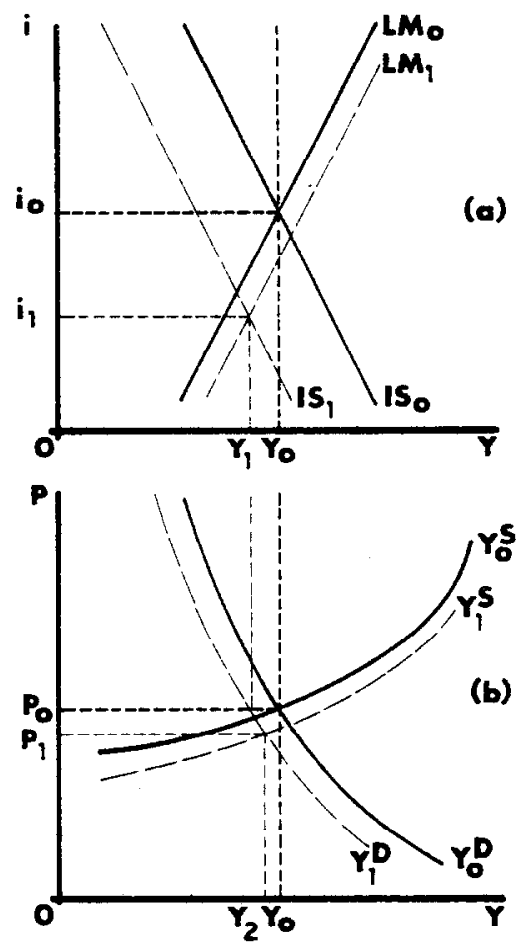

Figure 4. Wage restraint.

The reduction in government spending increases the government surplus and leaves the balance of trade surplus essentially unchanged, and the cumulative effect is a reduction in the monetary base. Thus over time, recession appears (or worsens).

\section{(c) Devaluation}

The differences between the MDC and LDC models are perhaps most evident when considering devaluation. In the MDC, devaluation improves the balance of trade shifting the $I S$ and $Y^{D}$ curves to the right, resulting in an increase in both output and the price level; restrictive monetary and fiscal policy are likely to be the appropriate stabilization policies to accompany devaluation.

In the LDC the analysis is more complex. For a given price level, devaluation shifts both the $I S$ and $L M$ curves to the left (to $I S_{1}$ and $L M_{1}$, respectively), resulting in a decrease in aggregate demand (to $Y_{1}^{B}$ ), but with an 
ambiguous impact on $i$ [shown with no change in Figure 3(a)]. Even with no change in the curb market interest rate, the aggregate supply curve shifts up to $Y_{1}^{s}$, since devaluation directly increases variable costs. The combined impacts are a major reduction in output [shown in Figure $3(b)$ as a fall from $Y_{0}$ to $Y_{2}$ ], perhaps with an increase in the price level [so drawn in Figure $3(\mathrm{~b})$, where $P$ rises from $P_{0}$ to $\left.P_{1}\right]$.

Although the fall in output suggests an expansionary cumulative effect, devaluation has a direct impact of reducing the monetary base. Tax revenues from trade increase in terms of domestic currency, while that balance-ofpayments surplus is assumed to decline. The net effect is ambiguous.

\section{(d) Incomes policy}

An incomes policy that lowers the nominal wage directly affects the standard LDC economy in a number of ways: (1) it shifts the IS curve to the left (under the assumption that the decrease in government spending and the redistribution of income away from workers have a large impact relative to the increased investment resulting from increased retained earnings); (2) it shifts the $L M$ curve to the right due to the decrease in the demand for money to finance working capital; and (3) it decreases both wage and interest costs, shifting the $Y^{s}$ curve down and to the right. These movements are shown in Figure 4 as shifts in $L M_{0}, I S_{0}$, and $Y_{0}^{S}$ to $L M_{1}, I S_{1}$, and $Y_{1}^{S}$. If the leftward shift in the $I S$ curve dominates the rightward shift in the $L M$ [as shown in Figure 4(a)], then there is a decrease in aggregate demand (from $Y_{0}^{D}$ to $\left.Y_{1}^{D}\right)$. If the impact of a wage decrease on government spending is large, or there is a substantial difference in the marginal propensity to consume for workers and capitalists, then the incomes policy will have the impact of decreasing both the price level and output. Such a change is shown in Figure 4(b), where $Y$ decreases slightly to $Y_{2}$. Alternatively, if the shift in the $Y^{D}$ curve is small (or even to the right), this incomes policy may produce an increase in output and employment. In the standard MDC model, on the other hand, a decrease in the rigid nominal wage would shift down the aggregate supply curve; output unambiguously rises, while the price level unambiguously falls.

If output increases (or decreases little) in the LDC, then the cumulative effect on the money supply is negative. This occurs through the usual income effect, and also the direct recuction in the government's wage bill. This gradual decrease in the money supply acts primarily to erode any output gains.

\section{CONCLUSION}

From the standard LDC macro model and the comparative static analyses of monetary, fiscal, exchange-rate and wage policies, one broad conclusion is clear: the traditional stabilization policies have very different, and generally less desirable, effects in LDCs than in advanced country models. Most notably, contractionary policy is likely to fuel, rather than dampen, inflationary tendencies. But there are other awkwardnesses, three of which merit attention. First, it is difficult to attack balance-of-payments crises, except through serious recession to cut back import demand. Second, all macro policies have effects on the government budget and the balance of payments, which affect the monetary base. This in turn severely limits policy-makers' ability to alter economic conditions in more than the very short run. Third, most restrictive policy is likely to worsen the income distribution.

These difficulties with short-run stabilization policy in LDCs indicate why policy-makers are - and indeed should be - so hesitant to undertake them. There are major conflicts between the means available to cure short-run crises and the long-run objectives of growth and equity. The high price of stability, in terms of other goals foregone or postponed, indicates why so many LDCs have been so reluctant to buy much of it.

\section{NOTES}

1. See Schydlowsky's chapter in Behrman and Hanson (1979) and Lecraw (1978), and the references cited therein.

2. One way to derive this function formaliy is to assume that firms maximize short-run quasi-rent (i.e. the excess of revenue over variable costs), with imports a fixed fraction of output $(m)$. The first-order condition is $[P-(1+i) e m] F_{N}=(1+i) w$, where $P$ is price, $F$ is the production function and $F_{N}$ is its derivative with respect to labour. Total differentiation implies equation (1). A straight oligopolistic mark-up of price over avervariable cost leads to the same qualitative result. 
3. If interest were paid on deposits, the households would have to choose between currency and deposits, and changes in the interest rate permitted would become a tool of monetary policy through the impact on the money multiplier.

4. The net worth of the commercial banks is also ignored, but this inclusion would affect little.

5. Hereafter, we shall use $i$ to represent the curb market interest rate and $i_{B}$ to represent the lower, fixed, bank lending rate.

6. The labour input $(N)$ is also endogenous but, since imported inputs are needed in fixed proportion to output, labour is uniquely related to output in the short run through the production function.

7. And the wage rate $(w)$ if we consider wage policy.

8. See Park (1973) and the studies therein cited. Studies that fail to detect interest elasticity in money demand are usually flawed by the inclusion of the rate of interest on government debt, commercial bank loans or commercial bank deposits - all of which are low, stable, and artificial in most LDCs. These same studies, on the other hand, always find that the rate of inflation is significant, and that of course, is of ten the major ingredient in the interest rate difference between money and curb market loans.

9. Other variables which are frequently introduced into MDC consumption functions, such as real wealth and the interest rate, are ignored here in order to focus on the differences between the LDC and the MDC.

10. Bruno (1979) assumes that the tax on profits exceeds that on wage incomes in LDCs. However, since LDCs rely more heavily on sales and excise taxes than income taxes, it is quite possible that the tax rate on wages is the larger. Our choice of a single $t_{y}$ essentially evades this issue.

11. Note that changes in the official bank loan rate $\left(i_{B}\right)$, which could be thought of as an instrument of monetary policy, has no effect on the $L M$ curve but does affect the $I S$ curve through its impact on retained earnings and hence investment.

12. The presence of quotas and licensing may break this dependence.

13. For further discussion of the export supply response to devaluation and export price changes see Krueger (1978) and Yotopoulos and Nugent (1976).

14. The derivation of equation (18) and its relation to the more familiar Marshall-Lerner condition is provided in the Appendix.

\section{Indeed, here we are assuming the $\epsilon_{M D}$ is zero.}

16. In fact, in the standard LDC model the effect on net exports shifts the IS curve to the right.

17. It is this aggregate supply curve, equation (23), that is drawn in the (b) parts of Figures $1-4$.

18. Note that the change in $P$ in turn shifts the $L M$ curve. As drawn, $P$ rises which means that the $L M$ curve shifts further to the left, further raising $i$. This final shift in the $L M$ curve is not drawn in Figure 1(a), to avoid cluttering it.

19. Again, and hereafter, the final shift in $L M$ due to the change in $P$ is not shown.

20. Within a full-employment, partial equilibrium model of the trade sector.

\section{REFERENCES}

Aghevli, B. B. and M. S. Khan, 'Government deficits and the inflationary process in developing countries', IMF Staff Papers (September 1978).

Ayre, P. C. I. (ed.), Finance in Developing Countries (London: Frank Cass, 1977).

Behrman, J. R., Review of L. Taylor, Macro Models for Developing Countries (McGraw-Hill, 1979) in Journal of Development Economics (February 1981).

Behrman, J. R., 'Sectoral investment determination in a developing economy', American Economic Review (December 1972).

Behrman, J. R. and J. A. Hanson (eds.), Short-Term Macroeconomic Policy in Latin Americe (Cambridge, Mass.: Ballinger, 1979).

Bruno, M., 'Stabilization and stagflation in a semiindustrialized economy', Chap. 8 of R. Dornbusch and J.A. Frenkel (eds.), International Economic Policy (Baltimore: Johns Hopkins Press, 1979).

Cardoso, E. A., 'Food supply and inflation', Journal of Development Economics (June 1981).

Cline, W. R. and S. Weintraub (eds.), Economic Stabilization in Developing Countries (Washington, D.C.: Brookings Institution, 1981).

Coats, W. L. and D. R. Khatkhate (eds.), Money and Monetary Policy in Less Developed Countries (Oxford: Pergamon Press, 1980).

Cooper, R. N., 'An assessment of currency devaluation in developing countries', in G. Ranis (ed.), Government and Economic Development (New Haven: Yale University Press, 1971).

Crockett, A. D., 'Stabilization policies in developing countries: some policy considerations', IMF Staff Papers (March 1981).

Diaz-Alejandro, C. F., Exchange-Rate Devaluation in a Semi-Industrialized Country (Cambridge, Mass.: MIT Press, 1965).

Fry, M.J., 'Saving, investment, growth, and the cost of financial repression', World Development (April 1980). 
Goldsmith, R. W., Financial Structure and Develop. ment (New Haven: Yale University Press, 1969).

Houthakker, H. S., 'An international comparison of personal savings', Bulletin of the International Statistical Institute, Vol. 38 (1961).

Krueger, A. O., Foreign Trade Regimes and Economic Development: Liberalization Attempts and Consequences (Cambridge, Mass.: Ballinger, 1978).

Krugman, P. and L. Taylor, 'Contractionary effects of devaluation', Journal of International Economics (August 1978).

Lecraw, D. J., 'Determinants of capacity utilization by firms in less developed countries', Journal of Development Economics (June 1978).

Leff, N. H. and K. Sato, 'Macroeconomic adjustment in developing countries: instability, short-run growth, and external dependency', Review of Economics and Statistics (May 1980).

McKinnon, R. I., Money and Copital in Economic Development (Washington, D.C.: Brookings Institution, 1973).

Park, Y. C., 'The role of money in stabilization policy in developing countries', IMF Staff Papers (July 1973).

Porter, R. C., 'Narrow security markets and monetary policy: lessons from Pakistan', Economic Development and Cultural Change (October 1965).

Rao, V. K. R. V., 'Investment, income, and the multiplier in an underdeveloped economy', Indian Economic Review (March 1952), reprinted in A. N. Agarwala and S. P. Singh (eds.), The Economics of Underdevelopment (London: Oxford University Press, 1958).

Schydlowsky, D. M., 'Short-run policy in semiindustrialized economies', Economic Development and Cultural Change (April 1971).

Selowsky, M., "Cost of price stabilization in an inflationary economy', Quarterly Journai of Economics (February 1973).

Sen, A., Employment, Technology, and Development (Oxford: Clarendon Press, 1975).

Turnham, D. and I. Jaeger, The Employment Problem in Less Developed Countries (Paris: OECD, 1970).

Williamson, J.G., 'Personal saving in developing nations: an intertemporal cross-section from Asia', Economic Record (June 1968).

Yotopoulos, P. A. and J. B. Nugent, Economics of Development: Empirical Investigations (New York: Harper and Row, 1976).

\section{APPENDIX}

It has been known for well over a half century now that devaluation does not necessarily improve the balance of payments. Whether it does or not depends upon conditions involving the (net) supply and demand elasticities of the devaluing country's exports and imports. ${ }^{20}$ In the recent discussions of macroeconomic policy in LDCs, this uncertainty about the effect of devaluation has played a central role, and we here look briefly at how the conditions for successful devaluation differ as the focus has moved from developed to underdeveloped economies.

A partial-equilibrium analysis of the net supplies and net demands of the exports and imports of the devaluing LDC, with the 'rest of the world' as the trading partner permits us to write the balance of payments in terms of the country's own currency $(B)$ as:

$$
B=e P_{x} X-e P_{m} M
$$

and in terms of some international currency $\left(B^{*}\right)$ as:

$$
B^{*}=P_{x} X-P_{m} M
$$

where $P_{x}$ and $P_{m}$ are the prices of exports and imports in international currency terms, $X$ and $M$ are the volumes of exports and imports, and $e$ is the exchange rate.

Taking derivatives, choosing units such that the initial world prices and exchange rate are one, and writing everything in terms of price elasticities (with the sign changed on demand elasticities to make them positive), we get:

$$
\begin{aligned}
d B / d e= & X\left[\epsilon_{X D}\left(1+\eta_{X S}\right) /\left(\epsilon_{X D}+\eta_{X S}\right)\right] \\
\text { and }{ }_{d B} / d e= & -M\left[\eta_{M S}\left(1-\epsilon_{M D}\right) /\left(\eta_{M S}+\epsilon_{M D}\right)\right] \\
& X\left[\eta_{X S}\left(\epsilon_{X D}-1\right) /\left(\epsilon_{X D}+\eta_{X S}\right)\right] \\
& -M\left[-\epsilon_{M D}\left(1+\eta_{M S}\right) /\left(\eta_{M S}+\epsilon_{M D}\right)\right]
\end{aligned}
$$

where $\eta$ represents supply elasticities and $\epsilon$ demand elasticities. Whether devaluation improves or worsens the balance of payments, in either currency, is uncertain because neither of these derivatives is necessarily positive.

Traditionally, economists take two approaches when considering developed countries. One is to uncover sufficient conditions for (A3) and (A4) being positive. In general, that sufficient condition is:

$$
\epsilon_{M D}>1 \text {, }
$$

or, if one further assumes that the initial balance of payments $\left(B\right.$ or $\left.B^{*}\right)$ is exactly in balance (i.e. $\left.X=M\right)$, the sufficient condition becomes

$$
\epsilon_{M D}+\epsilon_{X D}>1 \text {, }
$$

the wellknown Marshall-Lerner condition. The second approach is to search for necessary conditions while making some plausible assumptions about the quantitative magnitudes of some of the elasticities. For example, if one assumes that supplies are infinitely elastic, of exports from the devaluing country and of imports of the rest of the world, then condition (A6) above becomes the necessary condition for devaliation to improve the balance of payments, in either currency (again assuming trade to be initially balanced).

For less-developed economies, the econonist's approach to the signs of derivatives (A3) and (A4) is traditionally quite different. Trade is considered to be initially in deficit; and the small open economy assumption implies that the elasticities are infinite of the rest of the world's demand for the devaluing LDC's exports and the rest of the world's supply of the devaluing LDC's imports. Then derivative (A4) is always positive - devaluation must improve the 
balance of payments denominated in the foreign currency-but derivative (A3) is positive only if:

$$
B+X \eta X S+M \epsilon_{M D}>0
$$

The second and third terms of condition (A7) are necessarily positive, but the first term, representing the initial deficit, is negative and could conceivably offset the other terms. This possibility grows in probability if one further pictures the LDC export supply as price inelastic in the short run and the LDC demand for imports as determined by output rather than price in the short run. Both are so assumed in the standard LDC model - and hence inequality [equation (18)] - of the text.

For the developed countries, if the MarshallLerner conditions are met, the balance of payments improves regardless of the currency in which it is denominated. But for LDCs the currency matters. And the fact that devaluation must improve the international reserve position but may worsen the balance in terms of the domestic currency has two important implications for macroeconomic models. One, it is the balance in terms of the domestic currency that indicates the effect of the devaluation on aggregate demand; if that worsens, aggregate demand is reduced and the devaluation is contractionary. Two, it is the balance in terms of the domestic currency that indicates the effect of the devaluation on the monetary base; if that worsens, the monetary base is steadily reduced and the devaluation is cumulatively contractionary. 